Oliver, W. H. (1952). J. gen. Microbiol. 7, 329-334.

\title{
The Stability of some Bacterial Enzymes toward Heat and Chemical Bactericides
}

\author{
By W. H. OLIVER* \\ The Dairy Research Institute (N.Z.), Palmerston North, New Zealand
}

SUMMARY: The effect of heat, $\mathrm{HgCl}_{2}$ and cetrimide on decarboxylase systems of some typical lactic acid bacteria and coliform organisms has been investigated. The enzymes appeared to be reversibly inactivated by heat, for the cultures in milk and in broth retained considerable decarboxylase activity after having been heated to $100^{\circ}$ for $60 \mathrm{~min}$. Furthermore, decarboxylation continued after sterilization of the cultures with $\mathrm{HgCl}_{2}$ and with cetrimide.

It is well known that some enzymes even in an impure state can withstand temperatures considerably higher than that usually considered to cause irreversible denaturation of the protein moiety. Mellanby \& Woolley (1913), Van Slyke \& Cullen (1914), Stapp (1924), Bodansky (1924) and Northrop (1932) reported examples of stability of enzymes in the temperature range 80-100 ${ }^{\circ}$. Miyake \& Ito (1924) reported a diastase in Aspergillus oryzae which, although inactivated in a few seconds at $140^{\circ}$, required $130^{\circ}$ for $15 \mathrm{~min}$. and $120^{\circ}$ for $60 \mathrm{~min}$. for destruction. These appear to be the highest recorded temperatures at which any activity is retained by crude enzyme preparations. In spite of these early observations no one seems to have considered the possibility that bacterial enzymes might withstand the heat treatment commonly applied in pasteurization processes. The present work developed from the discovery of a heat-stable decarboxylase system in a strain of Streptococcus diacetilactis. The results show that bacterial enzyme systems may survive the killing of the organism by heat or bactericides and may continue under suitable conditions to produce characteristic end-products such as carbon dioxide and diacetyl.

\section{MATERIALS AND METHODS}

Test organisms. Four cultures of lactic streptococci were used. Two (DL and US) were strains of Strep. diacetilactis, a variant of Strep. cremoris with the unusual property of producing carbon dioxide, diacetyl and acetic acid in addition to the main-end product, lactic acid. This organism was first described by Matuzewski, Pijanowski \& Supińska (1937), and characterized in more detail by Thiel (1940). The third culture was a strain of Strep. cremoris (HP), and the fourth (MX13) was a dairy 'starter' containing a mixed flora of strains of Strep. lactis, Strep. cremoris and betacocci. The stock cultures were maintained in daily subculture in sterilized skim milk at $22^{\circ}$. All these cultures clotted milk within $24 \mathrm{hr}$. at $22^{\circ}$ and gave a maximum acid concentration of $c .0 \cdot 8 \%$ (calculated as lactic acid) within $36 \mathrm{hr}$.

\footnotetext{
* Present address: New Zealand College of Pharmacy, Wellington, New Zealand. 
Four strains of coliform organisms were used. According to the classification proposed by Wilson (1935) they were culture no. 5, Bacterium aerogenes, Type I; no. 13, Bacterium coli, Type II; no. 53, Intermediate, Type II; no. 83, Bact. aerogenes, Type II. All four strains produced a considerable amount of $\mathrm{CO}_{2}$ in milk and in broth. Strains, nos. 13, 53 and 83, continued to produce gas during incubation for 12 days at $37^{\circ}$ and strain 5 for 20 days. All the strains except no. 53 clotted skim milk at $37^{\circ}$ within 7 days. The stock cultures were maintained in daily subculture in sterilized skim milk at $37^{\circ}$.

Media. (i) Skim milk sterilized in the autoclave at $12 \mathrm{lb}$. for $20 \mathrm{~min}$. (ii) A broth containing 2.0\% lactose, $0.2 \%$ yeast extract (Oxoid), $1.0 \% \mathrm{Lab}$. Lemco, $1 \cdot 0 \%$ peptone, $\mathbf{0} \cdot \mathbf{8} \% \mathrm{Na}_{2} \mathrm{HPO}_{4}$ and sodium citrate sterilized as in (i).

Estimation of carbon dioxide. The $\mathrm{CO}_{2}$ produced during growth of a culture was estimated by absorption in $0 \cdot 1 \mathrm{~N}$-baryta which was subsequently backtitrated with $0 \cdot 1 \mathrm{~N}$-oxalic acid, the amount of $\mathrm{CO}_{2}$ being expressed in $\mathrm{ml}$. at N.T.P. The culture vessels were $150 \mathrm{ml}$. conical flasks containing $100 \mathrm{ml}$. of culture medium connected to absorption flasks also of $150 \mathrm{ml}$. capacity.

Estimation of diacetyl. The diacetyl produced was estimated colorimetrically by the method of Pien, Baisse \& Martin (1936) as modified by Cox \& Wiley (1939).

\section{RESULTS}

In preliminary work the practice was to inoculate twenty-one flasks of medium with the organism under test, connect the flasks to absorption vessels containing baryta, incubate at $\mathbf{2 2}^{\circ}$, and estimate the residual baryta in three flasks on each of seven successive days. The average of the three values obtained on each day was used to calculate the aggregate amount of $\mathrm{CO}_{2}$ formed by the culture up to that time. Later the procedure was simplified by detaching the absorption flasks each day for titration and replacing them immediately with flasks containing fresh baryta. In this way the $\mathrm{CO}_{2}$ production of the same three or four cultures was followed for the whole experimental period, with the advantage that possible variations from one culture flask to another were greatly reduced. This variation in procedure did not affect total $\mathrm{CO}_{2}$ production, although there was a tendency for the end-point to be reached a little earlier since the admission of oxygen to the system apparently influences slightly the rate of reaction but not the position of the end-point. Table 1 shows the cumulative volumes (at N.T.P.) of $\mathrm{CO}_{2}$ produced by the four cultures of lactic streptococci over a 7-day period. Culture HP, a typical Strep. cremoris, produced a negligible amount of $\mathrm{CO}_{2}$. The other cultures produced $\mathrm{CO}_{2}$ continuously during the 7 -day period, the total volume produced being similar for all three. All the cultures clotted the milk medium within the first $\mathbf{2 4} \mathrm{hr}$. and acid production was negligible from then on. The numbers of lactic acid bacteria in clotted milk cultures are known to be static and thus it is evident that continued $\mathrm{CO}_{2}$ production after the first $24 \mathrm{hr}$. under these conditions must be due to the metabolic activity of non-proliferating (socalled 'resting') bacterial cells. 
Table 1. Carbon dioxide produced by $100 \mathrm{ml}$. cultures of lactic streptococci in milk at $22^{\circ}$

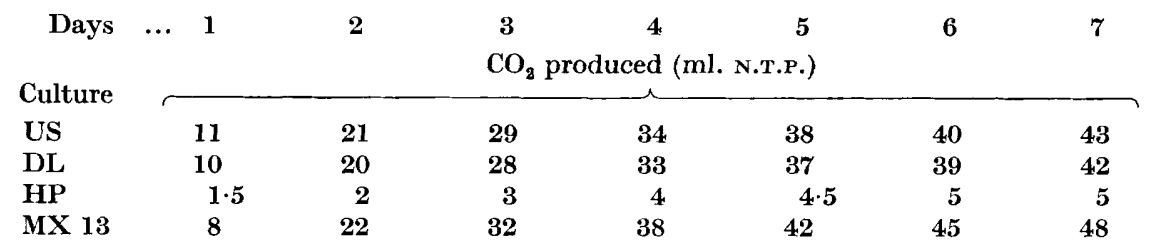

Controls of $100 \mathrm{ml}$. sterilized milk produced c. $2 \mathrm{ml}$. $\mathrm{CO}_{2}$ during the 7 -day period.

Carbon dioxide production after death of the bacteria

After the $\mathrm{CO}_{2}$-producing characteristics of the cultures had been established, experiments were set up in which some of the cultures, after growth under the described experimental conditions for various times, were treated in the following ways: (i) heated to $80^{\circ}$ for $2 \mathrm{~min}$. and rapidly cooled; (ii) heated to $100^{\circ}$ momentarily and rapidly cooled; (iii) treated with $\mathrm{HgCl}_{2}$ at a concentration of $0.2 \% \mathrm{w} / \mathrm{v}$ in the medium; (iv) treated with cetrimide $1 \% \mathrm{w} / \mathrm{v}$ (cetyltrimethylammonium bromide). Incubation and daily estimation of $\mathrm{CO}_{2}$ was continued with these flasks as with the controls for 7 days.

Table 2. Carbon dioxide produced by $100 \mathrm{ml}$. milk cultures of Strep. diacetilactis in 7 days at $22^{\circ}$, the organisms being killed at various times from the start of the experiment.

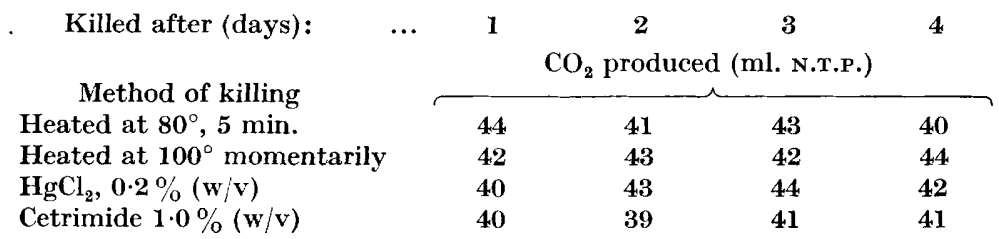

Controls (viable organisms) produced $42-43 \mathrm{ml}$. during the same period.

Table 2 gives some typical results with culture DL. It will be observed that the various treatments had no significant effect on the total volume of $\mathrm{CO}_{2}$ produced in 7 days. Similar results were obtained with all four cultures of lactic streptococci. The 'killed' cultures were tested for viable organisms after subjection to the various treatments by subculture into sterilized skim milk, and where $\mathrm{HgCl}_{2}$ had been used, $\mathrm{Na}_{2} \mathrm{~S}$ was added in slight excess to eliminate the effect of mercury ions transferred with the inoculum. All four treatments were found to have sterilized the cultures. It was thus clear that the killed lactic streptococci contained an enzyme system capable of producing $\mathrm{CO}_{2}$ in volumes similar to those produced by the viable bacteria.

\section{Thermal destruction point of the bacterial enzymes}

Preliminary trials indicated that the $\mathrm{CO}_{2}$-producing enzyme system of the lactic streptococci retained considerable activity after being heated at $100^{\circ}$ for $1 \mathrm{hr}$. in milk but that it was less stable in broth. A more precise heating 
technique permitted more detailed observations to be made. The flasks containing $100 \mathrm{ml}$. of culture and connected to $\mathrm{CO}_{2}$-absorption flasks were plunged into a large water-bath maintained at about $2^{\circ}$ above the desired temperature of treatment and agitated frequently. The time required for the culture fluid to reach the required temperature was checked by means of a thermometer in a control flask in the bath. After immersion for the desired time the flasks were removed from the bath and cooled in ice-water. In practice not more than $3 \mathrm{~min}$. were required to raise the temperature to $100^{\circ}$ and not more than $1 \mathrm{~min}$. to cool to room temperature. These relatively short times could not significantly affect the results. Table 3 gives the volumes of

Table 3. Carbon dioxide produced by $100 \mathrm{ml}$. cultures of Strep. diacetilactis during 5 days following the killing of the 2 -day cultures by heat treatment

\begin{tabular}{|c|c|c|c|c|c|c|}
\hline \multirow[t]{2}{*}{ Heated at $80^{\circ}$ for (min.) } & $\mathbf{5}$ & 15 & 30 & 40 & 60 & 120 \\
\hline & \multicolumn{6}{|c|}{$\mathrm{CO}_{2}$ produced (ml. N.T.P.) } \\
\hline Milk culture & 23 & 22 & 23 & 23 & 22 & 20 \\
\hline $\begin{array}{l}\text { Broth culture } \\
\text { Heated at } 100^{\circ}\end{array}$ & 25 & 22 & 21 & 20 & 19 & 18 \\
\hline Milk culture & 22 & 18 & 13 & 12 & 11 & 3 \\
\hline Broth culture & 18 & 15 & 4 & 3 & 3 & 2 \\
\hline
\end{tabular}

Controls (viable organisms) in milk and in broth produced c. 23 and $26 \mathrm{ml}$, respectively during the 5-day period.

$\mathrm{CO}_{2}$ produced in a subsequent 5 -day period at $22^{\circ}$ when cultures of strain DL after growth at $22^{\circ}$ for 2 days in skim milk and in broth were heat-treated as indicated in the table. These figures clearly indicate that the enzyme(s) concerned in $\mathrm{CO}_{2}$ production was remarkably heat-stable in milk culture. It retained $100 \%$ of its activity after heating at $80^{\circ}$ for $60 \mathrm{~min}$. and $45 \%$ at $100^{\circ}$ for $60 \mathrm{~min}$., whereas in broth the figures were $c .75$ and $13 \%$ respectively.

The possibility that prolonged heating might cause a significant chemical decarboxylation of the substrate in the medium was excluded by control experiments in which cultures were heated in the bath as described, and the gases evolved during heating were drawn off and bubbled through baryta solution. Estimation of the $\mathrm{CO}_{2}$ evolved gave a result never exceeding $2 \mathrm{ml}$. It is a common practice in work on decarboxylation by micro-organisms to deduct from the amount of $\mathrm{CO}_{2}$ produced by living cells the amount produced by boiled cell controls on the ground that the latter represents $\mathrm{CO}_{2}$ due to spontaneous decarboxylation in the presence of boiled cell material. Depending on the precise heat treatment given, on the culture medium used and on the micro-organism under investigation this practice could result in appreciable error, since the results detailed above show that in some cases $\mathrm{CO}_{2}$ production from boiled cells may arise from heat-stable enzyme systems.

\section{Production of carbon dioxide by killed coliform bacteria}

A few experiments on the same general lines as those described above were carried out with coliform bacteria in place of lactic streptococci. Cultures of all four strains after destruction by heat or disinfectants continued to produce 
$\mathrm{CO}_{2}$ as shown by the typical results for strain 13 given in Table 4 . The preliminary growth period in sterilized milk was 3 days at $37^{\circ}$ and the figures indicate that after the various treatments, which all sufficed to kill the organisms, $\mathrm{CO}_{2}$ production at $37^{\circ}$ in the subsequent $\gamma$ days was almost equal to that in the control. There was an indication that the decarboxylases present in coliform organisms were not quite as resistant to the treatments applied as were the decarboxylases of the lactic streptococci.

Table 4. Carbon dioxide produced by $100 \mathrm{ml}$. milk cultures of a coliform organism (strain 13) during the 7 days following the killing of the 3-day cultures by various treatments.

$\begin{array}{lc}\text { Method of killing } & \begin{array}{c}\mathrm{CO}_{2} \text { produced } \\ \text { (ml. N.T.P.) }\end{array} \\ \text { Heated at } 80^{\circ}, 5 \mathrm{~min} . & 39 \\ \text { Heated at } 100^{\circ}, 1 \mathrm{~min} . & 30 \\ \mathrm{HgCl}_{2}, 0 \cdot 2 \%(\mathrm{w} / \mathrm{v}) & 34 \\ \text { Cetrimide, } 1.0 \%(\mathrm{w} / \mathrm{v}) & 34 \\ \text { Control (viable organisms) } & 40\end{array}$

\section{DISCUSSION}

It has long been known that the velocity of enzyme-controlled reactions increases with rise in temperature to a maximum at about $50^{\circ}$ and decreases thereafter as the enzyme is progressively denatured, until at about $80^{\circ}$ most enzymes are irreversibly denatured. Bodansky (1924) believed that in some cases heat inactivation is reversible, but few investigations into the occurrence of such heat-stable enzymes appear to have been made. The present work indicates that among bacteria, heat-resistant enzyme systems may be quite widespread. From the fact that the activity of the decarboxylative enzymes of the lactic streptococei and coliform organisms ceased above $80^{\circ}$ but recommenced on a return to low temperature it appears that the phenomenon is due to a true reversible inactivation of the type reported by Bodansky. A few experiments indicated that the lactic streptococci of Strep. diacetilactis type continued to form diacetyl as well as $\mathrm{CO}_{2}$ after killing of the organisms.

This suggests that production of other relatively complex metabolic products by heat-stable enzyme systems in killed bacteria is likely.

The stability of the decarboxylase enzyme system towards a potent protein denaturant $\left(\mathrm{HgCl}_{2}\right)$ and a surface-active bactericide (cetrimide) is also remarkable, and there seems to be no other recorded instance of the phenomenon.

The present findings may have a wide significance especially in commercial processes where pasteurization procedures are used to destroy bacteria. In cheese manufacture, for instance, it is generally assumed that heat treatment of milk at $72^{\circ}$ for 15 sec. not only kills over $90 \%$ of the bacteria present as contaminants but that it also eliminates any further influence of these organisms on the final product. Since it appears that some of the bacterial enzyme systems can survive milk pasteurization this assumption is false. The heat-stable enzyme systems may have a significant influence on the cheeseripening process. (The production of gas, for instance, has an important 
bearing on the texture of cheese.) If this proves to be so the hygienic quality of the raw milk used after pasteurization for cheese manufacture is much more important than has generally been supposed because all enzymic reactions due to bacteria are not checked by the killing of the bacteria themselves.

The author gratefully acknowledges Dr H. R. Whitehead's assistance in designing experiments and in preparing the paper for publication, and also his helpful criticism and advice throughout the investigation.

\section{REFERENCES}

Bodansky, A. (1924). Study of a milk-coagulating enzyme of Solanum elaeagnifolium. J. biol. Chem. 61, 365.

Cox, G. A. \& Wiley, W. J. (1939). The colorimetric estimation of diacetyl and acetoin in dairy products. J. Coun. sci. industr. Res. Aust. 12, 227.

Matuzewski, T., PiJanowski, E. \& Supińska, J. (1937). A new lactic streptococcus as a constituent of butter starters. Int. Dairy Congr. Berlin, $2,80$.

Mellanby, J. \& Woolley, V. J. (1913). The ferments of the pancreas. III. The properties of trypsin, trypsinogen and enterokinase. J. Physiol. 47, 339.

MiYAKe, K. \& ITo, M. (1924). Lethal temperature of pure Koji-diastase in aqueous solutions and recovery of its action after heating. J. Biochem., Tokyo, 3, 177. (Chem. Abstr. 1924, 18, 1676.)

Northrop, J. H. (1932). Reversibility of the inactivation and denaturation of trypsin by heat. J. gen. Physiol. 16, 323.

Pien, J., Baisse, J. \& Martin, R. (1936). Contribution à l'étude du diacetyle. Lait, 16, 119.

STAPP, C. (1924). Contributions to the knowledge of bacterial enzymes. Zbl. Bakt. (I. Abt. Orig.), 92, 161.

Thies, C. C. (1940). The influence of various factors on the fermentation endproducts of the hetero-fermentative Streptococci. J. Dairy Res. 11, 51.

VAN Slyke, D. D. \& Cullen, G. E. (1914). The mode of action of urease. J. biol. Chem. 19, 141.

Wilson, G. S. (1935). The bacteriological grading of milk. Spec. Rep. Ser. med. Res. Coun. et al., Lond. no. 206.

(Received 7 April 1952) 